\title{
ROLE OF ANTIOXIDANT TREATMENTS IN IMPROVING POTATO YIELD AND QUALITY
}

(Received: 18.9.2006)

By

\author{
N. S. Youssef and E. M. M. Abd Allah \\ Vegetable Research Department, Horticulture Research Institute, \\ Agricultural Research Center, Giza, Egypt.
}

\begin{abstract}
This trial was conducted at Mallawy Agricultural Research Station, El-Minia, Egypt, during the summer seasons of 2003 and 2004 to investigate the role of some antioxidant treatments on potato yield and quality. Three antioxidants i.e. salicylic acid (SA), acetylsalicylic acid (Aspirin) (ASA) and n- propylgallate (PG) at three levels; 0.1, 0.5, and $1.0 \mathrm{Mm}$, were used as tuber seed soaking and foliar application treatments on potato plants, Solanum tuberosum L. cv. Diamant at the tuberization time. The results revealed that these antioxidants enhanced the content of chlorophyll $(\mathrm{Chl}) \mathrm{a}, \mathrm{b}$ and carotenoids in the leaves. Propylgallate at $0.5 \mathrm{mM}$ in both seasons and $1.0 \mathrm{mM}$ only in the second season gave the highest content of Chl. a, b and carotenoids. Also, SA at $0.5 \mathrm{mM}$ and ASA at all tested levels recorded a significant increase in carotenoids. However, 1.0 mM SA showed a decrease in this respect. $\mathrm{PG}$ at $1.0 \mathrm{mM}$ increased the tested pigments except Chl. a in the first season. The results indicated the importance of PG against photodamage of potato plants.

Significant increase in the plant height $(\mathrm{cm})$ was noticed with propylgallate $(\mathrm{PG})$ treatment in both seasons. The increment of plant height was corresponding with raising the concentrations. The other antioxidant treatments recorded the lowest values. Moreover, the increasing of SA or ASA levels, led to reduce plant height with insignificant differences as compared with the control. These results suggest that the higher concentration of ASA may be used as growth inhibitors, and the lower one as potato tuber promotion. Improvement in the reduction of the \% of potato feathering by using SA treatment at $1.0 \mathrm{mM}$ represents $24.86 \%$ and $27.48 \%$ in both seasons. The low levels of antioxidant treatments at $0.1 \mathrm{mM}$ showed the highest value of tuber grading (10.67\% with SA). The other levels of antioxidant treatments $(0.5$ and $1.0 \mathrm{mM})$ showed the lowest and decreased the unmarketable potato tubers. The highest percentage of potato tubers (over $340 \mathrm{~g}$ ) was obtained by using PG at $0.5 \mathrm{mM}$ in the first season and at $1.0 \mathrm{mM}$ in the second season ( $7.08 \%$ and $7.14 \%$ ) followed by PG at $0.5 \mathrm{mM}$ in the second season (5.99), whereas SA and ASA at $1.0 \mathrm{mM}$ showed a reverse effect.

PG at $1.0 \mathrm{mM}$ in the two seasons improved the increasing of the dry matter percentage, specific gravity, total yield (ton /fed.) which was (10.50\% in the first and $9.54 \%$ in the second season) and starch \% followed by SA at low levels $(0.1 \mathrm{mM}$ or $0.5 \mathrm{mM})$. Acetylsalicylic acid gave a highly effective reducing agent in improving the colour value. Also, low levels of SA, PG and ASA at 0.1 and $0.5 \mathrm{mM}$ showed improvement in the colour value. The obtained results could be summarized as follows: a- Propylgallate at $1.0 \mathrm{mM}$ improved the pigment contents yield (ton /fed.), plant height $(\mathrm{cm})$, dry matter, specific gravity, and starch. b- Low levels of these antioxidants improved the production of potato seed tubers. c- Improvement in the reduction of the potato feathering $\%$ was recorded by using SA at $1.0 \mathrm{mM}$. So, SA may play a role in the promotion of senescence (aging, effects of old age) at the highest level. d- Acetylsalicylic acid (Aspirin) was effective in improving the colour value of potato tubers.
\end{abstract}

Key words: acetylisalicylic acid, propylgallate, salicylic acid, Solanum tuberosum L.

\section{INTRODUCTION}

Antioxidants a class of nutrients in human health that protect the body from damage caused by different factors (Karadeniz et al., 2005), has prompted research in the fields of food science and horticulture to assess fruit and vegetable antioxidants (Kalt et al., 1999). The majority of the antioxidant capacity of fruits or vegetables may be from some compounds such as falvonoids, isofalvonoids,flavones, isoflavones, anthocyanins, catechins, vitamin C, E or $\beta$ carotene (Kähkönen et al., 1999). Many of these phytochemicals may help to protect cells against oxidative damage caused by free radicals (Wada and $\mathrm{Ou}, 2002$ ). Antioxidants intercept free radicals and protect cells from the oxidative damage that leads to aging 
and disease (Karadeniz et al., 2005). Active oxygen scavengers (antioxidants) should be beneficial in the protection of the structure and function of the photosystems against excess light. (Rajagopal et al., 2005). Also, Antioxidants play role in the reduction or prevention of enzymatic browning by inhibiting polyphenol oxidase (Maurice et al., 2000).

Salicylic acid (SA, 2-hydroxy benzoic acid) is a natural cellular component (Raskin et al., 1990), a natural phenolic compound (Klessige and Malamy, 1994), a natural growth regulator (Zhou et al., 1999), a signal transduction or messenger (Klessig and Malamy, 1994). It has the ability to induce systemic acquired resistance (SAR) to pathogens (Raskin, 1992; Galal et al., 2001 and Kawano et al., 2004), and may enhance chilling and drought resistance in plants (Senaratna $e t$ al., 2000). It gave heat tolerance (Pan et al., 2006). It is present in many plant species at various levels. The concentration of endogenous SA varied significantly from tissue to tissue and from species to species (Raskin et al., 1989). SA uptake was $\mathrm{pH}$ - dependent (Chen and Kuc', 1999). The function of SA excretion is unclear (Chen et al., 2001). However, accumulation of SA in cells may affect some physiological functions and cause cytotoxicity (Kapulnik et al., 1992). Exogenous application of SA induced pathogenesis-related gene expression and SAR (Bi et al., 1995). Senaratna et al., (2000) showed that the concentrations over $1.0 \mathrm{mM}$ of acetylsalicylic acid or salicylic acid appeared to have adverse effects and therefore lower concentrations were used in most experiments. Studies by Munne-Bosch and Penuelas, 2003) concluded that moderate doses of SA enhance the antioxidant status and induce stress resistance; higher concentrations activate a hypersensitive cell death pathway and increase stress sensitivity. Also, Lopez-Delgado and Scott (1997) noted growth retardant effects of ASA on potato microplants in vitro at $10^{(-4)}-10^{(-3)} \mathrm{mol} / \mathrm{l}$. The followed work indicating that ASA was more effective than salicylic acid in potato tissue culture (Lopez-Delgado et al., 1998). Koda et al. (1992) excluded the possibility of the involvement of SA in natural tuberization of potato plants.

Acetylsalicylic acid (aspirin;2-acetoxybenzoic acid) has been used for $>100$ years for pain (Paterson et al., 2006) It is one of the basic preparation used in the therapy of cardiovascular diseases, leads to irreversible reduction of platelet aggregation (Stejskal et al., 2001). Salicylic acid is widely present in plants and functions as a hormonal mediator of the systemic acquired resistance response to pathogen attack and environmental stress. Thus, it is present in a large range of fruits, vegetables, herbs and spices of dietary relevance. The recognized effect of consuming fruits and vegetables on lowering risk of colon cancer may be partly attributable to salicylates in plant-based foods (Paterson et al., 2006). The results by Godoy-Hernandez and Loyola-Vargas(1997)suggested that acetylsalicylic acid (Aspirin) (ASA) could act as a new biotic elicitor of metabolite production in Catharanthus roseus cell suspension cultures.

Propylgallate, (Three hydroxyl groups) is alkyl ester of gallic acid. It has strong antioxidant effect in foods, and blocks activity of lipoxygenase (Stejskal et al., 2001) which make it very reactive, lower solubility, tend to chelate trace minerals such as iron and form colored complexes. It can inhibit ethylene production in fruit slices, flowers and vegetative tissues (Elad 1992). Plants contain a number of different pigments - including the carotenes and the xanthophylls - that are thought to protect from light stress. These pigments also play a role in capturing light and in maintaining the structure of the membrane (Johnson et al. 1993). The protective role of reactive oxygen scavengers against photodamage was significantly protected in the presence of histidine or $\mathrm{n}$ - propylgallate, chlorophyll photobleaching resulting in a decrease and retarded the damages to the antenna proteins, as reported by Zolla and Rinalducci (2002) and Rajagopal et al., (2005). Also, it removes the hydroxyl radicals (Sonoike, 1996), and provided complete protection against light induced protein aggregation in isolated thylakoids Roberts et al., (1991). Shelf life of peeled and cut potatoes is strongly limited by enzymatic browning that leads to a decrease in food quality (Limbo and Piergiovanni, 2006). It can be retarded by eliminating oxygen from the cut surface. However, this is not always feasible. The common way of inhibiting the enzymatic browning of peeled and sliced potatoes is to dip, or immerse, them in anti-browning agents. Among, such as ascorbic acid or citric acid through its ability to reduce quinines to phenolic compounds or its inhibitory effect on polyphenol oxidase (PPO) (Iyengar and McEvil, 1992). Dry matter is generally used as an index of starch content by breeders and growers (Gould and Plimpton, 1985) Tubers with high dry matter content require less energy and absorb less oil during frying, and have a drier texture after cocking (Storey and Davis, 1992). LopezDelgado et al., (2004) reported that external application of salicylate could enhance tuber industrial quality by increasing dry matter and starch content. The objectives of this study were 
to assess responses of potato plants to some antioxidants to improve the quality and productivity, find the best treatment to prevent the browning development of potato tuber slices for potato processing, as well as reducing the risks of potato consumption.

\section{MATERIALS AND METHODS}

Two field experiments were carried out in the two successive summer seasons of 2003 and 2004 at the Experimental Farm of Mallawy Agricultural Research Station, El-Minia, Egypt on potato cv. Diamant. Imported potato seed

\begin{tabular}{|l|l|ll|}
\hline Treatments & Concentrations (mM) & \multicolumn{2}{|c|}{ Form } \\
\hline Salicylic acid (SA) & $0.1,0.5,1.0$ & $\mathrm{C}_{7} \mathrm{H}_{6} \mathrm{O}_{3} \quad$ Molecular Weight $\quad(\mathrm{MW})=138.12 \mathrm{~g} / \mathrm{mol}$ \\
\hline Propylgallate (PG) & $0.1,0.5,1.0$ & $\mathrm{C}_{10} \mathrm{H}_{12} \mathrm{O}_{5} \quad$ MW. 212.2 \\
\hline Acetylsalicylic acid (ASA) & $0.1,0.5,1.0$ & $\mathrm{C}_{9} \mathrm{H}_{8} \mathrm{O}_{4} \quad$ MW. 180.16 \\
\hline Control (tap water) & & $\mathrm{H}_{2} \mathrm{O} \quad$ MW. 18.02 \\
\hline
\end{tabular}

tubers were purchased and held in a semi dark room at room temperature $\left(20^{\circ} \mathrm{C} \pm 2\right)$ for two weeks to green sprouting $(1.0 \mathrm{~cm}$ length) before cuttings. Seed tuber was sized by diameter, cut into $50-60 \mathrm{~g}$ pieces 2-3 days before planting. Each piece had not less than two active eyes. Then different antioxidant treatments were used as follows: These treatments were prepared and the $\mathrm{pH}$ value and the reduction in the $\mathrm{pH}$ solution at different concentration were recorded in Table (1).

Table (1): $\mathrm{pH}$ values and the \% of $\mathrm{pH}$ reduction of water solution treated individually with SA, PG and ASA at $0.1,0.5$ and $1.0 \mathrm{mM}$.

\begin{tabular}{|lc|c|c|}
\hline Treatment & Concen. $(\mathbf{m M})$ & pH value & Reduction \% in pH solution \\
\hline Salicylic acid (SA) & 0.1 & 3.50 & 52.70 \\
\hline & 0.5 & 3.10 & 58.10 \\
\hline Propylgallate (PG) & 1.0 & 2.80 & 62.11 \\
\hline & 0.1 & 5.90 & 20.27 \\
\hline & 0.5 & 5.80 & 21.62 \\
\hline Acetylsalicylic acid (ASA) & 1.0 & 5.70 & 22.97 \\
\hline & 0.1 & 4.10 & 44.59 \\
\hline & 0.5 & 3.30 & 55.40 \\
\hline Control (tap water) & 1.0 & 3.00 & 59.45 \\
\hline
\end{tabular}

Table (2): Some physical and chemical properties of the soil at depth of $0-30 \mathrm{~cm}$ (average of the two seasons).

\begin{tabular}{|c|c|c|c|c|c|c|c|c|c|c|c|}
\hline $\begin{array}{c}\text { Texture } \\
\text { grade }\end{array}$ & Sand & Silt & Clay & pH & E.C & CEC & $\mathbf{C a C O}_{3}$ & O. M & \multicolumn{2}{|c|}{ Available nutrient (ppm) } \\
\hline Clay loam & $7.63 \%$ & $61.87 \%$ & $30.50 \%$ & 7.9 & 1.12 & $36.45 \%$ & $2.08 \%$ & $1.09 \%$ & 45.13 & 11.25 & 82.30 \\
\hline
\end{tabular}

Table (3):Tubers yield (ton/fed.) of potato cv. Diamant as affected by some antioxidant treatments (SA, PG and ASA) at 0.1, 0.5 and $1.0 \mathrm{mM}$ in the first and the second summer seasons.

\begin{tabular}{|c|c|c|c|}
\hline \multirow{2}{*}{\multicolumn{2}{|c|}{$\begin{array}{c}\text { Antioxidant treatments } \\
(\mathrm{mM})\end{array}$}} & \multicolumn{2}{|c|}{ Yield (ton/fed.) } \\
\hline & & First season (2003) & Second season (2004) \\
\hline $\mathrm{SA}$ & 0.1 & $11.724 \quad \mathrm{~B}$ & $13.38 \quad \mathrm{C}$ \\
\hline & 0.5 & $12.302 \mathrm{AB}$ & $14.21 \mathrm{~B}$ \\
\hline & 1.0 & $11.847 \quad \mathrm{~B}$ & $12.27 \mathrm{D}$ \\
\hline PG & 0.1 & $11.703 \quad \mathrm{~B}$ & $14.14 \quad \mathrm{~B}$ \\
\hline & 0.5 & $11.945 \mathrm{~B}$ & $14.20 \mathrm{~B}$ \\
\hline & 1.0 & $12.880 \mathrm{~A}$ & $14.57 \mathrm{~A}$ \\
\hline $\mathrm{ASA}$ & 0.1 & $11.737 \quad \mathrm{~B}$ & $13.28 \mathrm{C}$ \\
\hline & 0.5 & 11.885 & 13.28 \\
\hline & 1.0 & 11.995 & 13.34 \\
\hline Contr & & 11.656 & 13.30 \\
\hline
\end{tabular}


These treatments were applied by soaking the potato seed tuber pieces for $24 \mathrm{~h}$ in one of the above solutions then, rinsed and left at room temperature for 1-2 days before plantings. The planting dates were January $20^{\text {th }}$ and $23^{\text {rd }}$ in the first and the second summer seasons respectively. Hills were $25 \mathrm{~cm}$ apart within row spacing. Each experimental plot consisted of 3 rows, $3 \mathrm{~m}$ length and $75 \mathrm{~cm}$ apart. At the time of the tuberization after 45, 60 and 75 days from planting an additional dose of the same treatments were applied as foliar application on potato plants. The experiment treatments were arranged in a randomized complete block design with three replicates. Other agricultural practices for potato production were followed as recommended by the Ministry of Agriculture, and potato requirements for fertilization was in accordance to the available nutrients illustrated in Table(2).

\subsection{Pigment analysis:}

After 3 days from the third foliar treatments (78 days after planting) pigments were determined. Fresh leaves $(1 \mathrm{~g})$ were taken from these treatments, homogenized in a mortar with $5 \mathrm{ml}$ of $80 \%(\mathrm{v} / \mathrm{v})$ acetone containing $\mathrm{CaCO}_{3}$ as described by Gilmore and Yamamoto (1991). The extract was centrifuged at $10.000 \mathrm{~g}$ for $15 \mathrm{~min}$ at $4^{\circ} \mathrm{C}$. The supernatant was stored in the dark at $5^{\circ} \mathrm{C}$, while $3 \mathrm{ml}$ of the solvent were added to the pellet and recentrifuged, this procedure repeated twice. The total supernatant was brought to a final volume of $10 \mathrm{ml}$. the concentration of chlorophyll a, b and carotenoids was determined by reading the absorbance of the extract at $663 \mathrm{~nm}$ for chlorophyll a, $644 \mathrm{~nm}$ for chlorophyll $\mathrm{b}$ and $440.50 \mathrm{~nm}$ for carotenoids. Calculations for pigments (Chl. a, Chl. b and carotenoids) were derived from the equations of Arnon (1949). All spectrophotometric assays were performed using a Milton Roy Spectrophotometer (Milton Roy Spectronic 1201).

2.2. Plant height $(\mathbf{c m})$ : Plant height was recorded at harvest time, after 110 days from planting.

2.3. Percentage of feathering: was recorded in accordance to Muriel et al., (1976)

2.4. Yield and its components: Percentage of potato tubers was taken in this study according to Zvomuya and Rosen (2001), under three categories:

2.4.1. Marketable potato seed tubers $(85-340 \mathrm{~g})$ :

2.4.2. Unmarketable potato tubers less than $85 \mathrm{~g}$ :

2.4.3. Tubers over $340 \mathrm{~g}$ :

2.4.4. Tuber yield (ton/fed.)

2.5.Tuber quality:

2.5.1. Dry matter, was evaluated according to A.O.A.C (1990)
2.5.2.Specific gravity, was measured as described by Sinha, et al., (1992).

2.5.3. Starch \%, was calculated as described by Yildrim and Tokusoglu (2005) using the following equation. Starch $\%=17.546+199.07 \times$ (specific gravity-1.098)

\subsection{Color characteristics}

Color measurements of potato tubers were detected as described by Matus-Cadiz et al., (2003) and Kaur and Singh (2005). Flour samples (slicing, dried at $70^{\circ} \mathrm{C}$ for $48 \mathrm{~h}$ and ground) were carried out using a Hunter Colorimeter (Color Tec PCM Associates, Inc. N. J. USA) on the basis of $\mathrm{L}, \mathrm{a}$ and $\mathrm{b}$ values. $\mathrm{L}-$ value designates the lightness of the sample $(100=$ white and zero = black $), a$ values designates redness when positive or greenness when negative, and b- values designate yellowness when positive or blueness when negative. Individual samples were placed in a sample container that had a glass bottom, and opaque sides. The container was placed over the aperture of the colorimeter. Four readings from each treatment were obtained by rotating the container at 90 angles.

The instrument was calibrated against a standard red-coloured reference tile

$$
\mathrm{L}_{\mathrm{s}}=25.54, \mathrm{a}_{\mathrm{s}}=28.89, \mathrm{~b}_{\mathrm{s}}=12.03
$$

Total colour differences (TCD) were calculated by applying the equation

$\mathrm{TCD}=\left[\left(\mathrm{L}_{\mathrm{s}}-\mathrm{L}\right)^{2}+\left(\mathrm{a}_{\mathrm{s}}-\mathrm{a}\right)^{2}+\left(\mathrm{b}_{\mathrm{s}}-\mathrm{b}\right)^{2}\right]^{1 / 2} \quad($ Kaur and Singh, 2005 and Limpo and Piergiovani, 2006)

2.7. Statistical analysis: All recorded data were subjected to the analysis of variance procedures and treatment means were compared using the Duncan as described by Duncan (1955).

\subsection{Pigment analysis}

SA, PG and ASA treatment enhanced the content of the Chl. a, b and carotenoids in the leaves (Fig. 1). Propylgallate at $0.5 \mathrm{mM}$ in both seasons and $1.0 \mathrm{mM}$ only in the second season showed the highest content of Chl. a. Also, SA at $0.5 \mathrm{mM}$ and ASA at all tested levels recorded a significant increase with insignificant differences between them. On the other hand, PG at $1.0 \mathrm{mM}$ increased these pigments, except $\mathrm{Chl}$ a in the first season. These results revealed the importance of PG against potato plants photodamage. Also, these results agree with Rajagopal et al., 2005 who reported that photooxidation was significantly protected in the presence of n-propylgallate and the chlorophyll photobleaching resulting in a decrease. The 
specific action of $\mathrm{PG}$ indicates that singlet oxygen $\left({ }^{1} \mathrm{O}_{2}\right)$ was the main form of reactive oxygen species (ROS) responsible for strong light-induced damage. Acetylsalicylic acid and PG at $1.0 \mathrm{mM}$ scored the highest values of carotenoids in both seasons; carotenoids are the scavenger of ${ }^{1} \mathrm{O}_{2}$ and are known to protect chlorophyll and the photosynthetic membrane from photo-oxidation damage (SiefermannHarmms, 1987). Similarly, ASA at 0.1, 0.5 and $1.0 \mathrm{mM}$ increased carotenoids in the first season with insignificant differences among them. However, 1.0 mM SA in both seasons decreased the levels of all major pigments. The results of SA treatment are in agreement with those reported by Rao et al., (1997) who implied that leaves treated with $1.0 \mathrm{mM}$ SA did not enhance the content of chl. a or Chl. b. However, $0.5 \mathrm{mM}$ SA decreased all major pigments. Also, Chen et al., (2001) showed that SA could induce AOS generation, and enhanced $\mathrm{H}_{2} \mathrm{O}_{2}$ production (Kauss and Jeblick, 1994 and Rao et al., 1997) and $0.5 \mathrm{mM} \mathrm{SA}$ caused super oxide generation (Kawano et al., 1998). $\quad \mathrm{H}_{2} \mathrm{O}_{2}$ regulation which may play a critical role in the onset and dynamics of senescence and leaf senescence in particular may involve degradation of chlorophyll (Hodges and Forney, 2000)

\subsection{Plant height}

The data showed significant increase in the plant height $(\mathrm{cm})$ by using probylgallate $(\mathrm{PG})$ at the three levels in both seasons (Fig. 2). This effect was more noticed by raising the concentrations of PG to $1.0 \mathrm{mM}(66.27 \mathrm{~cm}$ and $70.45 \mathrm{~cm}$ in the first and the second season, respectively). The antioxidant treatment with ASA at $1.0 \mathrm{mM}$ in the two seasons recorded the lowest values. So, increasing the SA or ASA levels decreased plant height causing insignificant differences with the control treatment. Lopez-Delgado and Scott, (1996) noted the growth retardant effects of ASA on potato microplants in vitro at $10^{-4}-10^{-3} \mathrm{~mol} / \mathrm{l}$. The mechanism of the effects of salicylates on plant growth rate is poorly understood, and the physiological importance of these effects is not clear (Pierpoint, 1994 and Lopez-Delgado and Scott, 1996).

\subsection{Percentage of feathering}

The results presented in Fig.(3) indicate that potato seed tuber soaking and foliar treatments 3 times at the time of tuberization with ASA at 1.0 $\mathrm{mM}$ had positive and significant effects on increasing potato feathering after harvest in both seasons giving 25.27 and $38.71 \%$ (in the first and second seasons, respectively) compared to the control (19.79\% and $32.85 \%)$. Also, PG at $1.0 \mathrm{mM}$ scored $40.00 \%$ but only in the second season. On the other hand, SA treatments significantly decreased the potato feathering in the two seasons. The lowest values were obtained by SA at $1.0 \mathrm{mM}$ which gave $14.87 \%$ in the first season and $23.82 \%$ in the second season. The reduction in the potato feathering with using SA treatment at $1.0 \mathrm{mM}$ represent ranged from $24.86 \%$ to $27.48 \%$ in the first and second seasons, respectively. These results suggested that SA may play a role accelerating potato maturing and promote senescence. In this regard Munne-Bosch and Penuelas (2003) and Bordersen et al., (2005) reported that the high concentrations of SA activated hypersensitive cell death (HR).

\subsubsection{Percentage of marketable potato seed tubers $(85-340 \mathrm{~g})$}

The data presented in Fig. 4a and $4 \mathrm{~b}$ showed that low levels of antioxidant treatments (SA, PG and ASA) at $0.1 \mathrm{mM}$, improved the culturable potato seed tubers without significant differences among them. Thereby, PG at the same level gave the highest value $(58.23 \%)$, whereas it was $56.72 \%$ for ASA and $56.07 \%$ for SA compared with the control in the first season. The improving percentage represents $14.94 \%$ with PG, 11.96 with ASA and $10.67 \%$ with SA. Also, in the second season SA only at $0.1 \mathrm{mM}$ gave the highest value $(58.30 \%)$ which represents $14.13 \%$. The other levels of antioxidant treatments $(0.5$ and $1.0 \mathrm{mM})$ showed the lowest values without significant differences between them in both seasons. Decreased stem height by ASA at high levels (Lopez-Delgado et al. 1998) may be due to increased the tuberization. Also, Lopez-Delgado et al.,(2004) found useful effects of medium supplemented with salicylate in the promotion of tuberization.

\subsection{Percentage of unmarketable potato} tubers (less than 85g)

At $0.1 \mathrm{mM}$, the three antioxidant treatments slightly decreased the unmarketable potato seed tuber by $35.86 \%$ for PG and $36.76 \%$ for ASA in the first season. No significant differences were detected between them as shown in Figs. $4 \mathrm{a}$ and $4 \mathrm{~b}$. The reduction was $23.94 \%$ for $\mathrm{PG}$, $22.03 \%$ for ASA and $16.56 \%$ for SA. The highest concentrations of SA $(0.5$ and $1.0 \mathrm{mM})$ and ASA at $1.0 \mathrm{mM}$ induced an increase of the unmarketable potato tubers but these increases were insignificant. PG at 0.5 or $1.0 \mathrm{mM}$ had slightly positive effect. From the previous studies by Lopez- Delgado et al., (1998 and 
2004) and the data presented in this study ASA can be used as growth inhibitor and promoter for potato tuberization and its effect is concentration dependent.

\subsubsection{Percentage of tubers over $340 \mathrm{~g}$}

Among the three antioxidant treatments tested, the best result was obtained with $\mathrm{PG}$ at $0.5 \mathrm{mM}$ in the first season and at $1.0 \mathrm{mM}$ in the second season which gave $7.08 \%$ and $7.14 \%$, respectively followed by $\mathrm{PG}$ at $0.5 \mathrm{mM}$ in the second season (5.99\%). However, the control gave $2.09 \%$ and $3.91 \%$ in the first and the second seasons, respectively. On the contrary, the highest levels of SA and ASA (at $1.0 \mathrm{mM}$ ) decreased the percentage of tubers more than $40 \mathrm{~g}$ with insignificant difference with the control.

\subsubsection{Total yield (ton/fed.)}

The obtained data in Fig. 8 and Table(3), revealed that potato yield as ton/fed. increased insignificantly with the most antioxidant treatments in both seasons, except with PG at 1.0 $\mathrm{mM}$, in the first and PG at three levels in the second season, as compared with the control. This increase was significant with $\mathrm{PG}$ at $1.0 \mathrm{mM}$ in both seasons and represented 10.50 and $9.54 \%$ in the first and second season. On the other hand, SA at $1.0 \mathrm{mM}$ caused a significant decrease in the total yield (ton/fed.) in the second season compared with the control. This decrease represents $7.74 \%$ over the control. The reason may be due to cytotoxicity of SA. This explanation was reported by Kapulnik et al., (1992) who mentioned that the accumulation of SA in the cells may affect their physiological functions and cause cytotoxicity. Also, the low level of the pigments, play a role in capturing light and in maintaining the structure of the membrane (Johnson et al., 1993) as well as inhibiting the mineral uptake by changing the plasma membrane permeability (Einhellig, 1986) Also, Rao et al., (1997) showed that leaves treated with SA exhibited greater damage to cellular pigments and organelles. Also, the $\mathrm{pH}$ reduction which represents $62.11 \% \mathrm{SA}$ at $1.0 \mathrm{mM}$ may play a role in mineral uptake compared to $22.97 \%$ with PG Table (1). The reasons for yield improvement by PG treatments may be due to the stimulation of photosynthesis, percentage of photooxidation and chlorophyll photobleaching resulting in a decrease in Chl. a, b and carotenoids. Also, n-propylgallate retarded the damages of the antennas proteins indicating mainly that singlet oxygen $\left({ }^{1} \mathrm{O}_{2}\right)$ was involved in the degradation of PsaB gene product into two fragments, these fragments were absent with added n-propylgallate, which remove hydroxyl radical $\left(\mathrm{OH}^{-}\right)$(Rajagopal et al., 2005).
The data presented in Fig. 5 show substantial increase in the percentage of potato tuber dry matter with PG, SA and ASA compared with the control. These results agree with the results by Lopez-Delgado et al., (2004) who reported that external application of salicylate could enhance industrial quality by increasing the dry matter and starch. Significant increases with increasing levels of PG were detected. This increase was more pronounced in $\mathrm{PG}$ at $1.0 \mathrm{mM}$ in both seasons $(20.35 \%$ and $20.18 \%$ ) followed by ASA at 0.1 $\mathrm{mM}$ in the first season $(19.47 \%)$ and $0.5 \mathrm{mM} \mathrm{SA}$ in the second season $(19.00 \%)$. Significant differences between the levels of antioxidant treatments were noticed. The increments with PG at $1.0 \mathrm{mM}$ may be due to the stimulation of photosynthesis which has been indicated previously because of the positive effect of PG on increasing pigment content.

\subsection{Specific gravity}

In spite of the increments of this quality character in the first seasons compared with the control, these increases were insignificant (Fig. 6). Significant increase in specific gravity in the second season was recorded by the application of PG at 1.0 $\mathrm{mM}$ which gave 1.082 followed by ASA at $1.0 \mathrm{mM}$ (1.074), PG at $0.5 \mathrm{mM}$ (1.074), SA at $0.5 \mathrm{mM}$ (1.074) and SA at $0.1 \mathrm{mM}$ as compared with the control, as well as the other of treatments. In the mean time, insignificant effects were detected among these positive treatments. On the other hand, the effects of all treatments were insignificant in the first season. These result may be due to a varietal character and the genotype effects

\subsection{Percentage of starch}

Application of SA at 0.1 and $0.5 \mathrm{mM}, \mathrm{PG}$ at 0.5 and $1.0 \mathrm{mM}$ and ASA at $0.1 \mathrm{mM}$ in the two seasons gave the highest values with insignificant differences among them (Fig. 7). The highest values were recorded with $\mathrm{PG}$ at $1.0 \mathrm{mM}$ in both seasons $(13.55$ and $13.20 \%$ ) compared with the control (11.81 and $11.70 \%$ ). In contrary, high levels of SA or ASA caused a slight increase in the percentage of starch. This increase by low levels of SA may be due to the enhancement of $\mathrm{H}_{2} \mathrm{O}_{2}$ production by salicylate treatments. In this respect, many authors showed a strong relation between $\mathrm{SA}$ and $\mathrm{H}_{2} \mathrm{O}_{2}$. LopezDelgado et al. (2005) showed that $\mathrm{H}_{2} \mathrm{O}_{2}$ treatments significantly enhanced potato tuber starch accumulation ranged $6.7 \%$ to $30.0 \%$ aas determined by the specific gravity. Also the increment by PG treatment may be due to the stimulation of the photosynthesis process.

\subsection{Color characteristics}

The data illustrated in Figs. 9. and 2B. showed

\subsection{Dry matter $(\%)$}




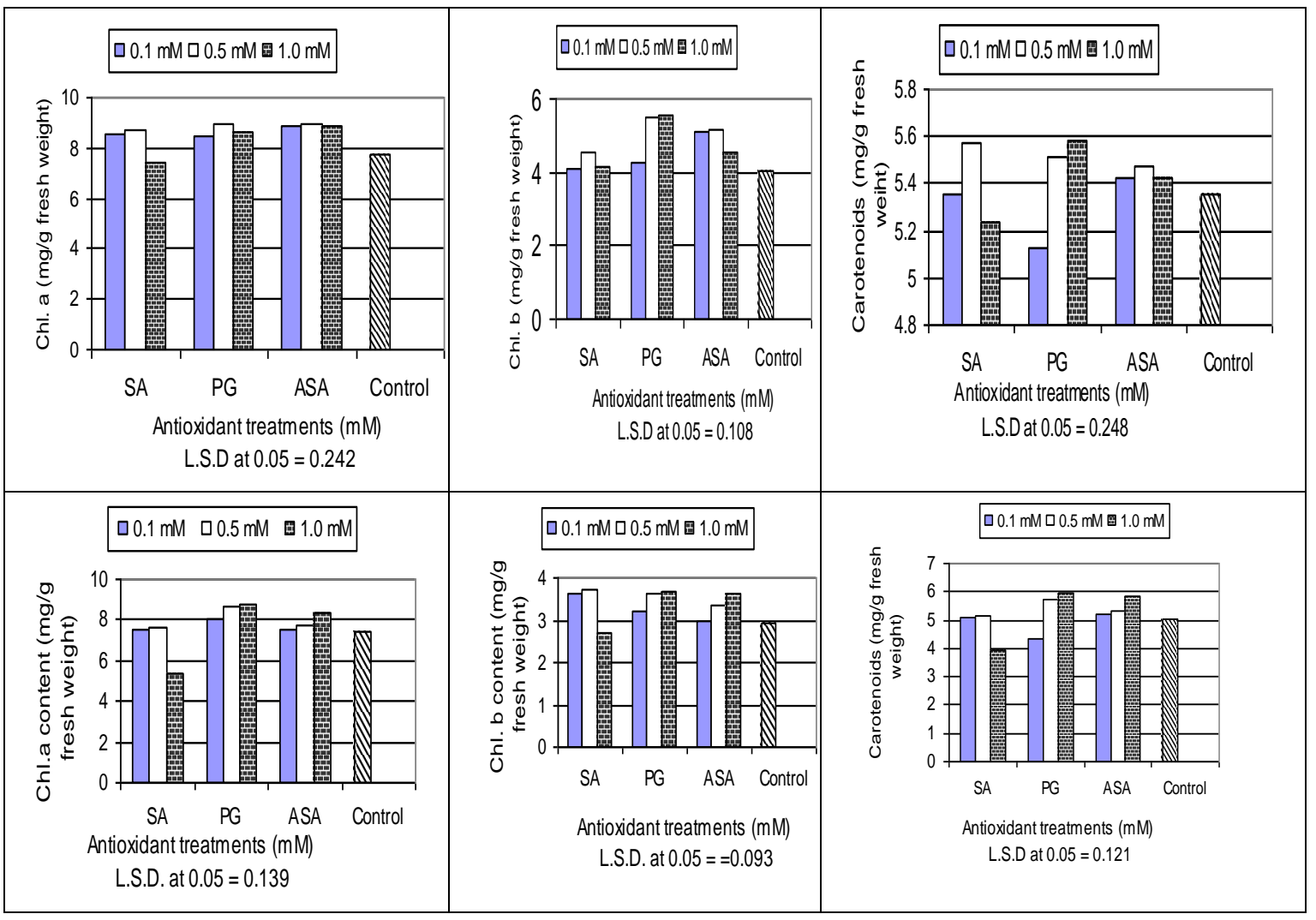

Fig. (1): Chlorophyll,a, b and Carotenoid content (mg/g fresh weight) of the leaves of potato plants cv. "Diamant" as affected by some antioxidant treatments (SA, PG and ASA) at different concentrations in the first (top) and the second summer seasons(bottom).

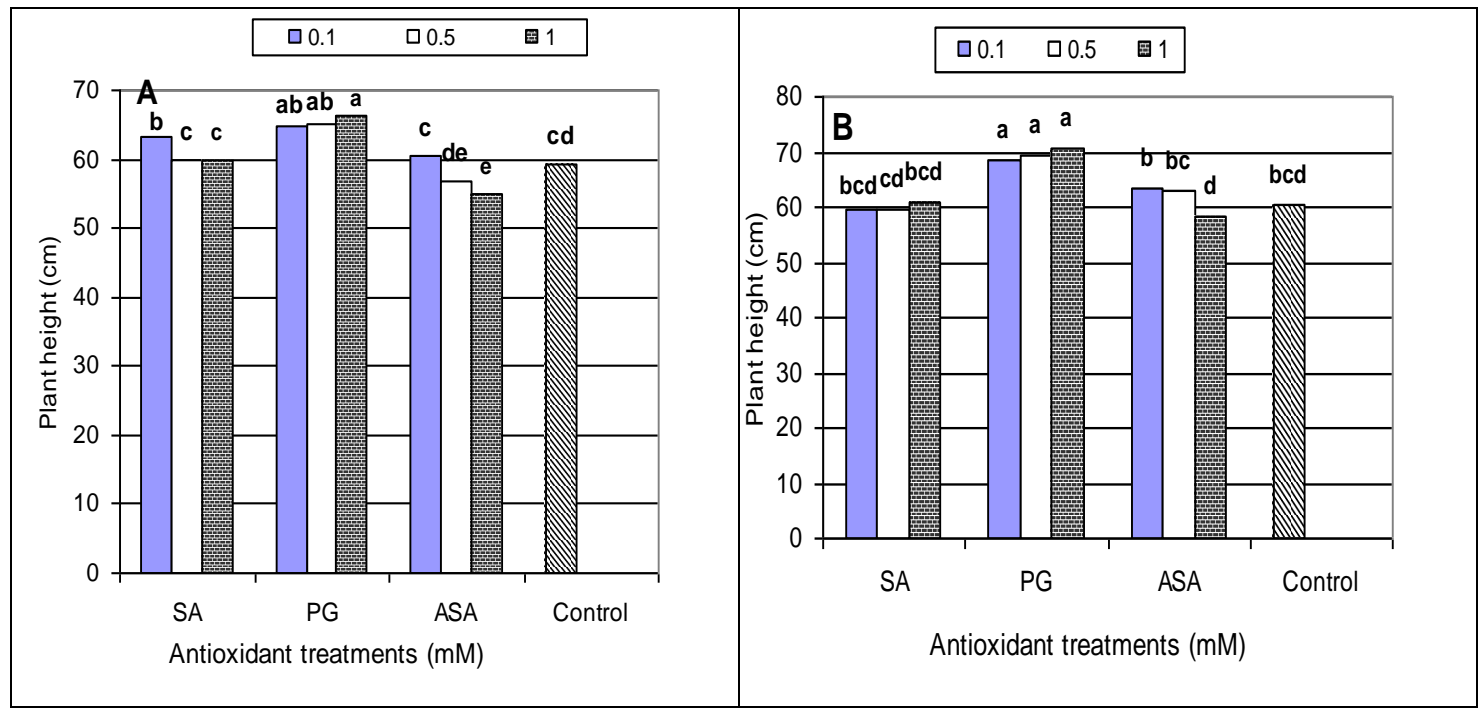

Values with similar alphabetical letter do not significantly differ from each other, using Duncan's Multiple Range test, at 0.05 levels

Fig. (2): Plant height $(\mathrm{cm})$ of potato plants cv. "Diamant" as affected by some antioxidant treatments (SA, PG and ASA) at different concentrations in two successive seasons (2003 \& 2004) . 


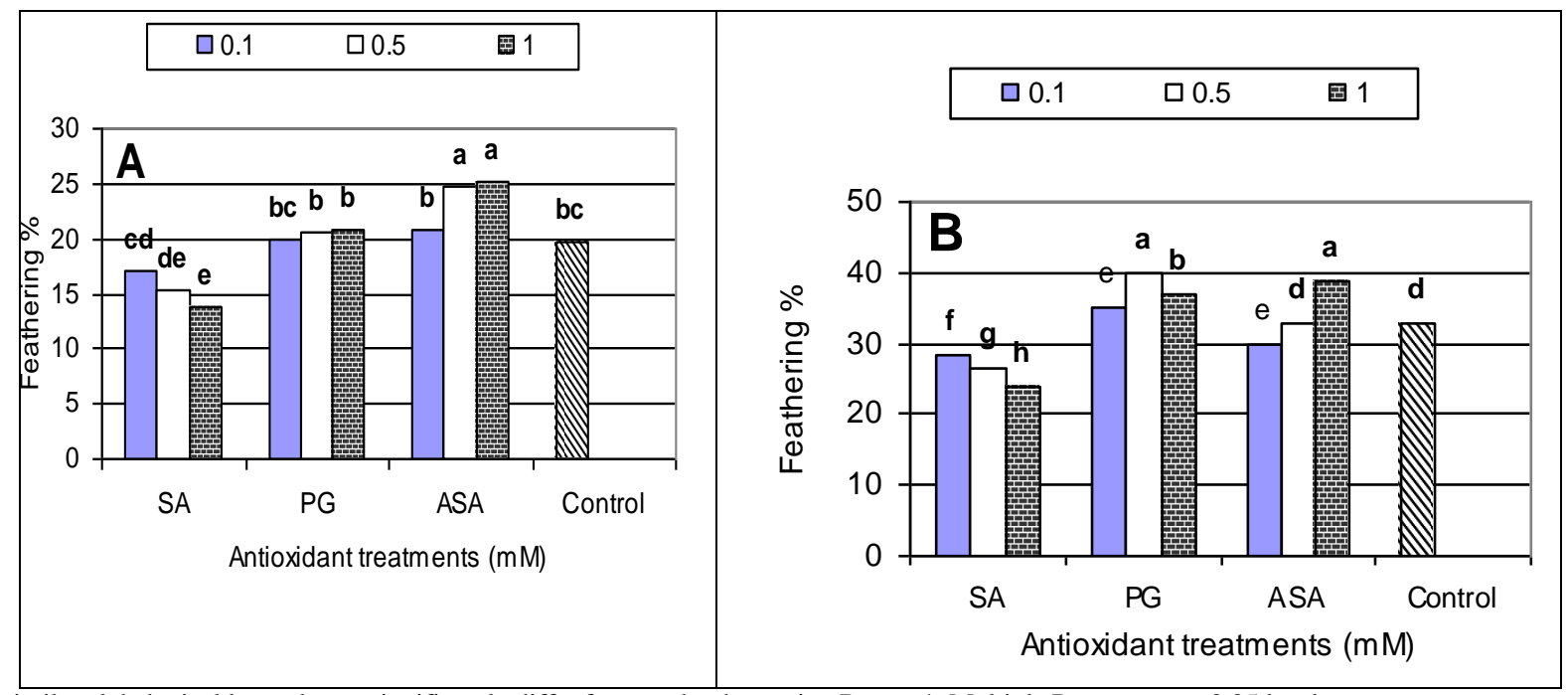

Values with similar alphabetical letter do not significantly differ from each other, using Duncan's Multiple Range test, at 0.05 levels.

Fig. (3): Percentage of feathering potato tubers cv. "Diamant" as affected by some antioxidant treatments (SA, PG and ASA) at different concentrations in the first (A) and the second (B) summer seasons of 2003 and 2004.

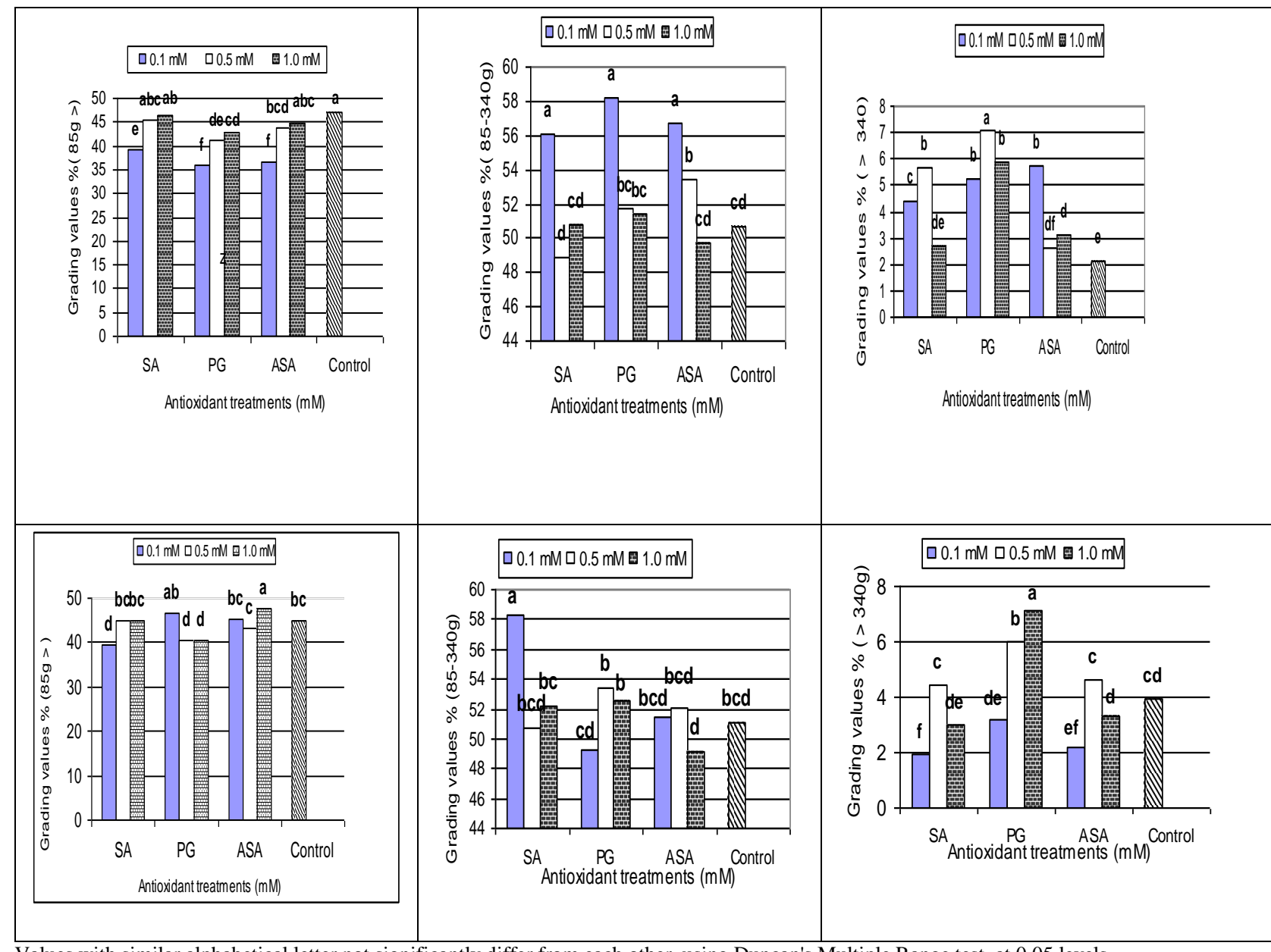

Values with similar alphabetical letter not significantly differ from each other, using Duncan's Multiple Range test, at 0.05 levels.

Fig. (4a): Tuber grading \% $(<85 \mathrm{~g}, 85-340 \mathrm{~g}$ and $340 \mathrm{~g}<)$ as affected by antioxidant treatments $(\mathrm{mM})$ (SA, PG and ASA) in the first (top) and the second season (bottom). 


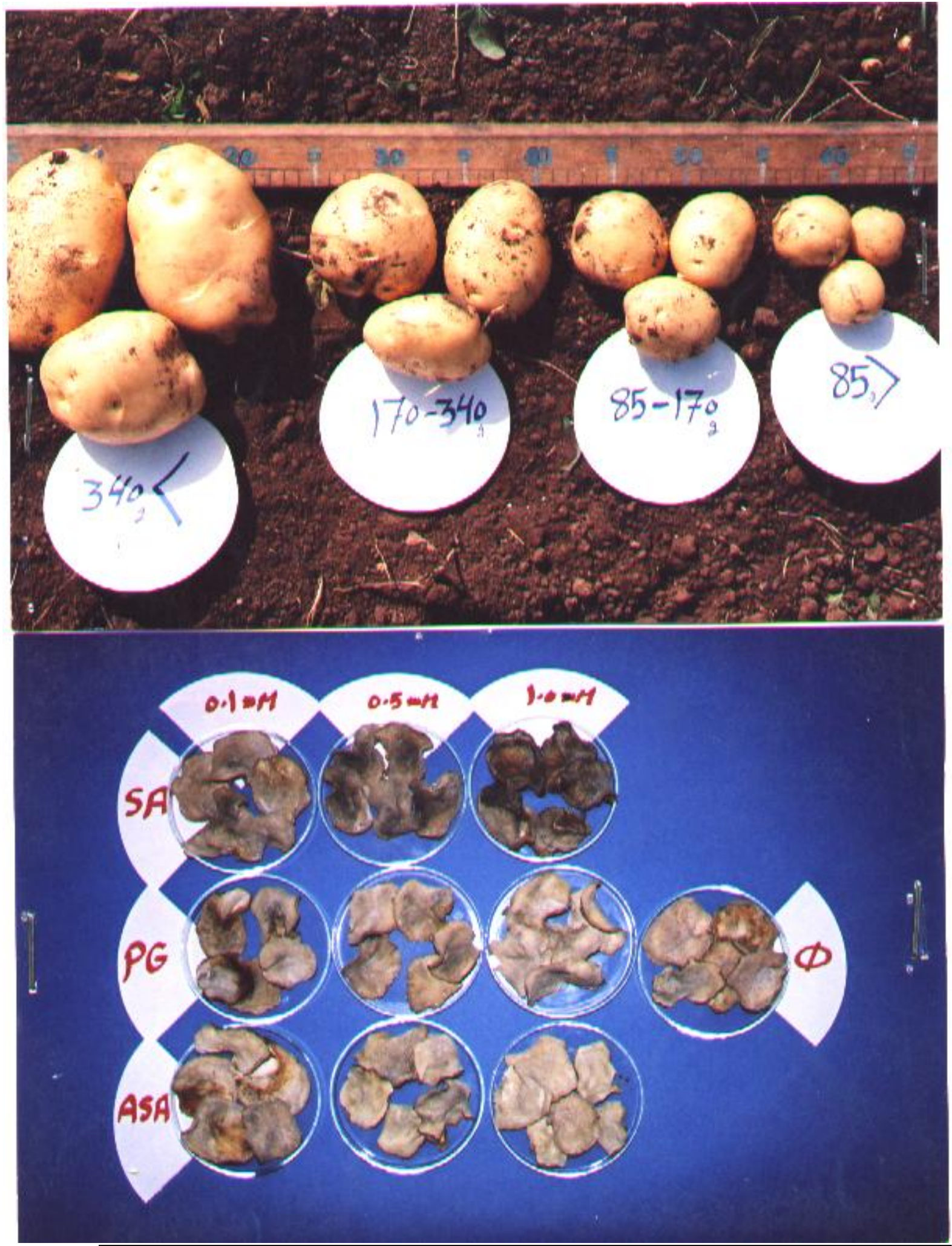

Fig. 4b. A: Scale based on tuber weight for potato tuber grading (g) $85,85-170$, 170-340 and 340

B: colors of potato tuber slices as affected by SA, ASA and PG at 0.1, 0.5 and $1.0 \mathrm{mM}$ 


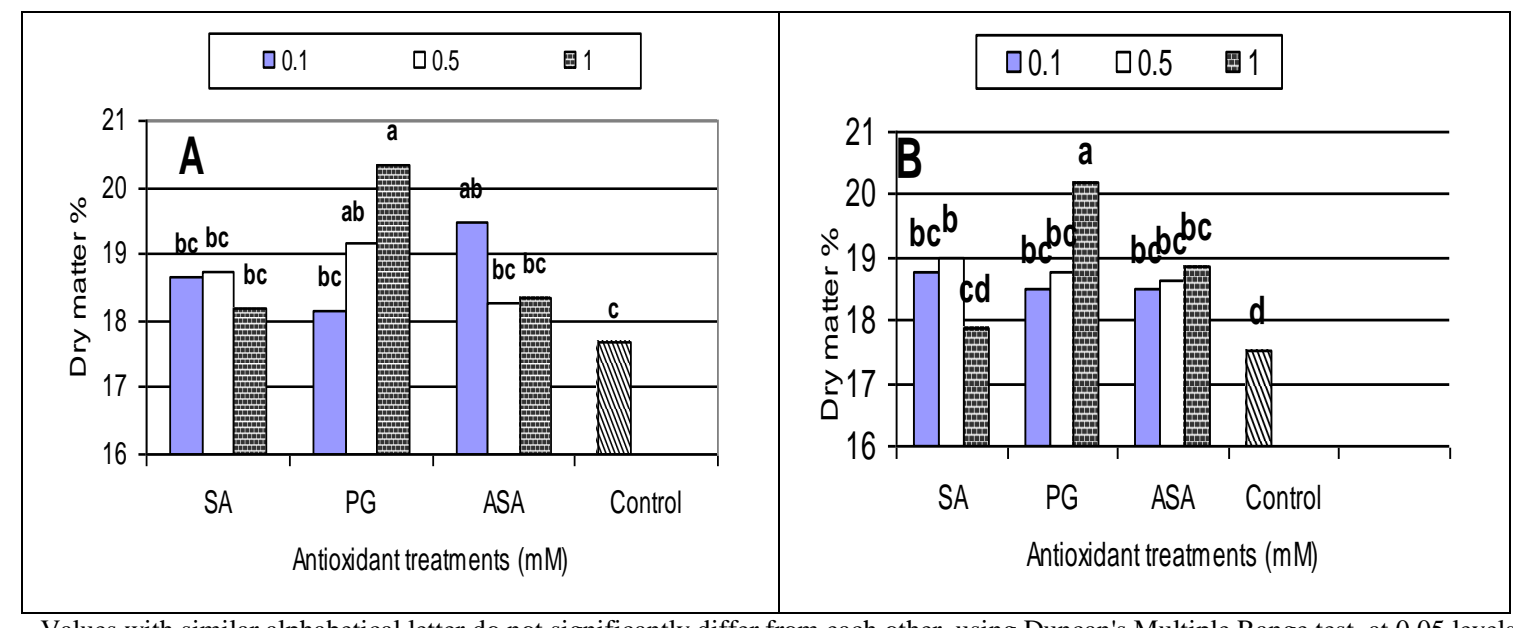

Values with similar alphabetical letter do not significantly differ from each other, using Duncan's Multiple Range test, at 0.05 levels.

Fig. (5): Tuber dry matter \% of potato tubers cv. "Diamant" as affected by some antioxidant treatments

(SA, PG and ASA) at 0.1, 0.5 and $1.0 \mathrm{mM}$ in the first (A) and the second (B) summer seasons of 2003 and 2004.

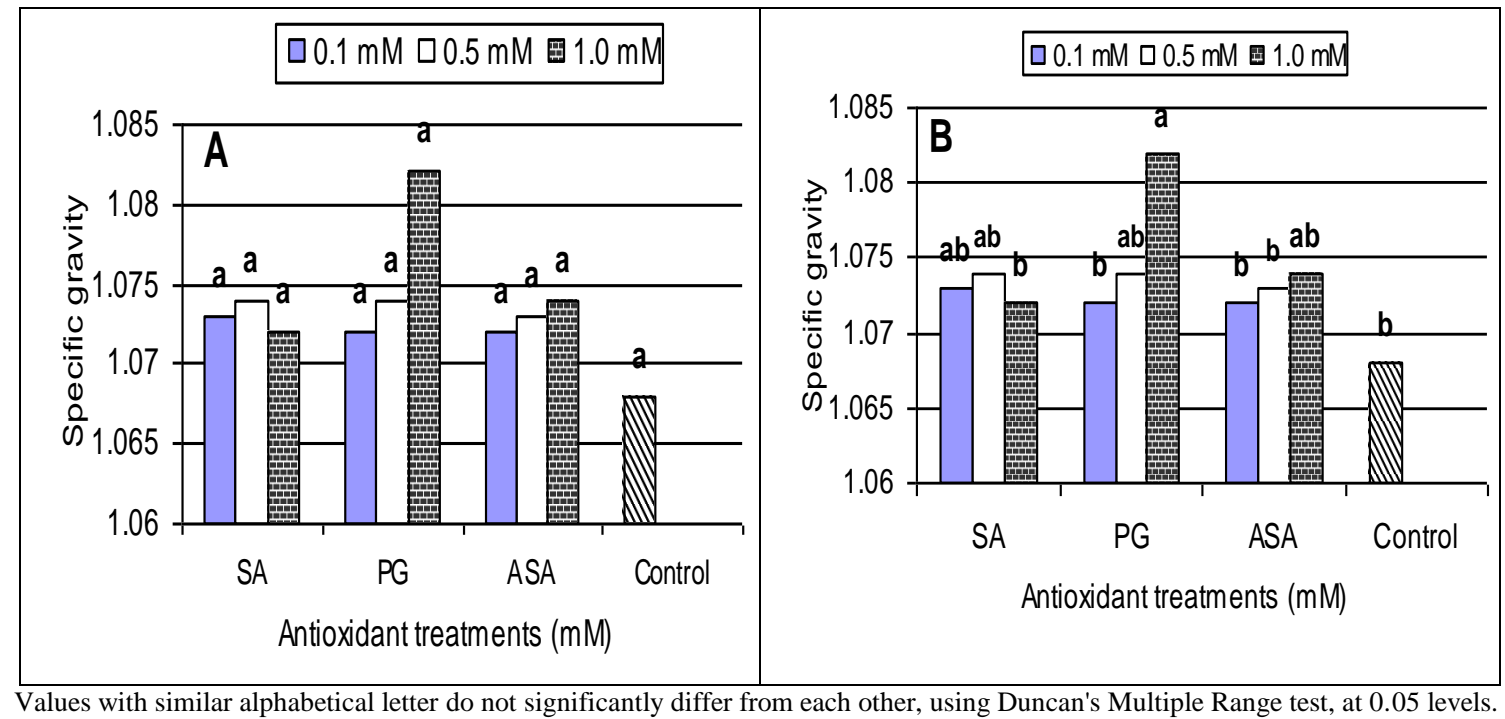

Fig. (6): Specific gravity (Sp.Gr) of potato tubers cv. "Diamant" as affected by some antioxidant treatments (SA, PG and ASA) at different treatmentsin the first and the second summer seasons of 2003 and 2004.

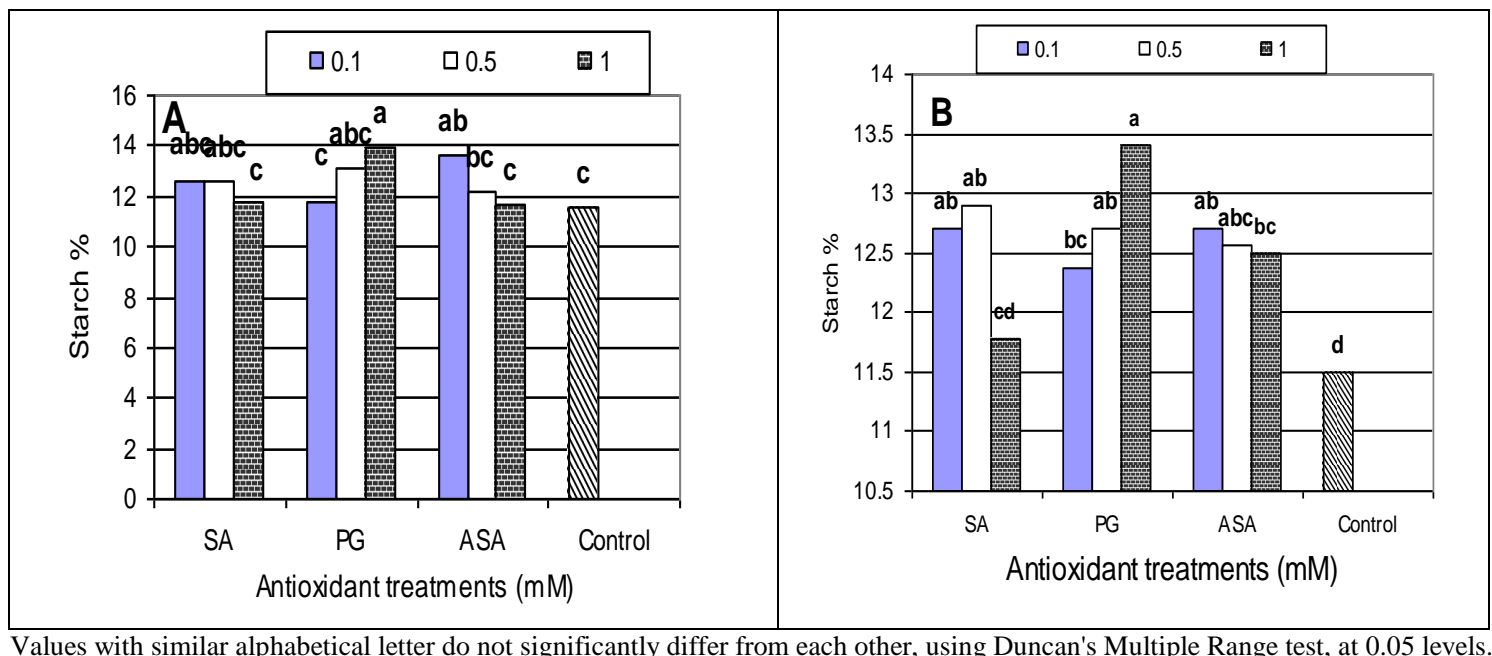

Fig.(7): Percentage of starch of potato tubers cv. "Diamant" as affected by some antioxidant treatments (SA, PG and ASA) at 0.1, 0.5 and 1.0 mM in the first and the second summer seasons of 2003 and 2004. 


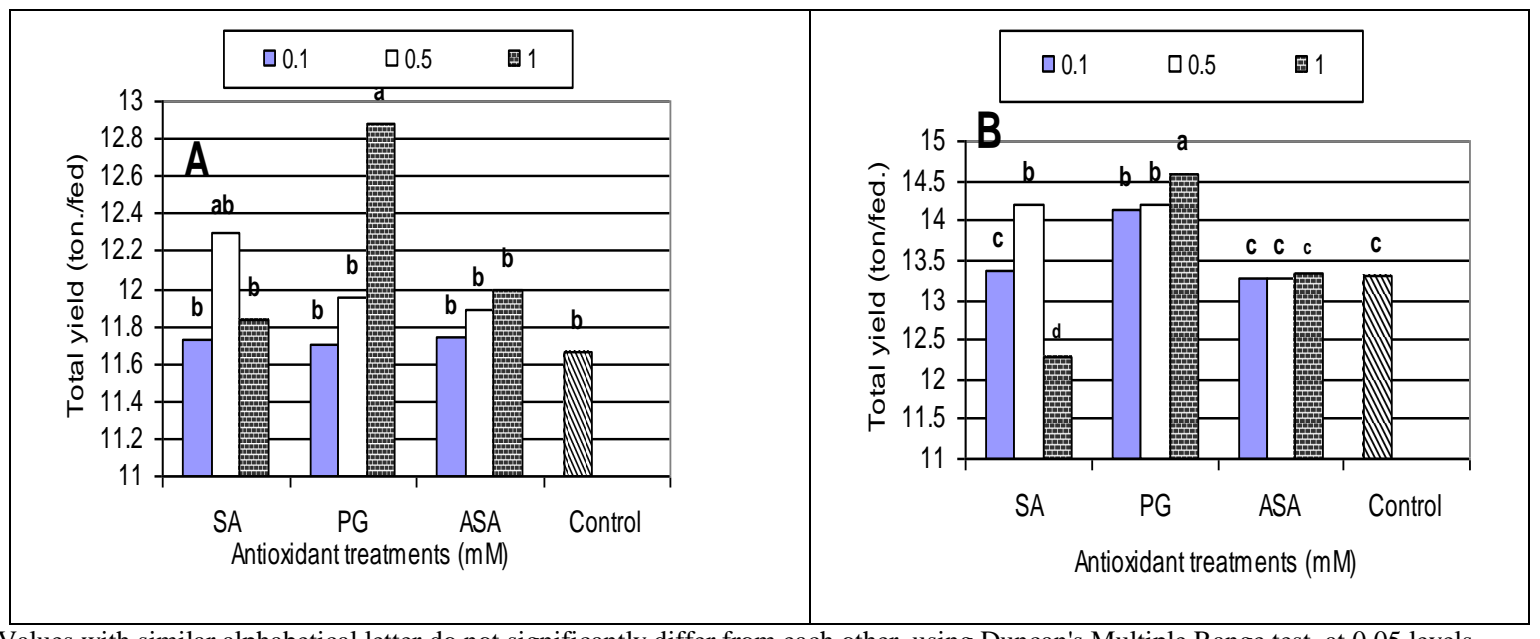

Values with similar alphabetical letter do not significantly differ from each other, using Duncan's Multiple Range test, at 0.05 levels.

Fig. (8): Yield (ton/fed.) of potato tubers cv. "Diamant" as affected by some antioxidant treatments

(SA, PG and ASA) at different concentrations in the first and the second summer seasons of 2003 and 2004.

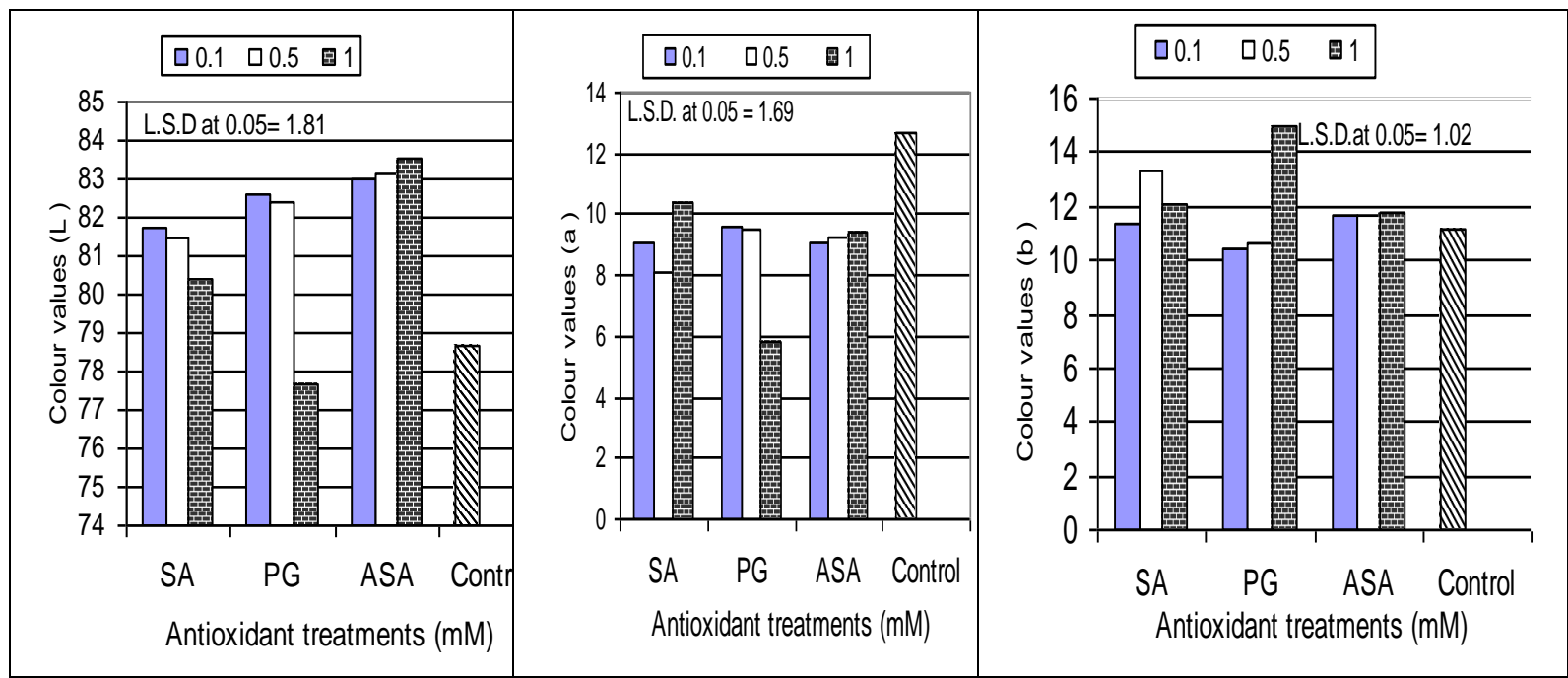

Values with similar alphabetical letter do not significantly differ from each other, using Duncan's Multiple Range test, at 0.05 levels $\mathrm{L}=100$ (white) to zero (black); $\mathrm{a}=+$ (red); $\mathrm{b}=+$ (yellow)

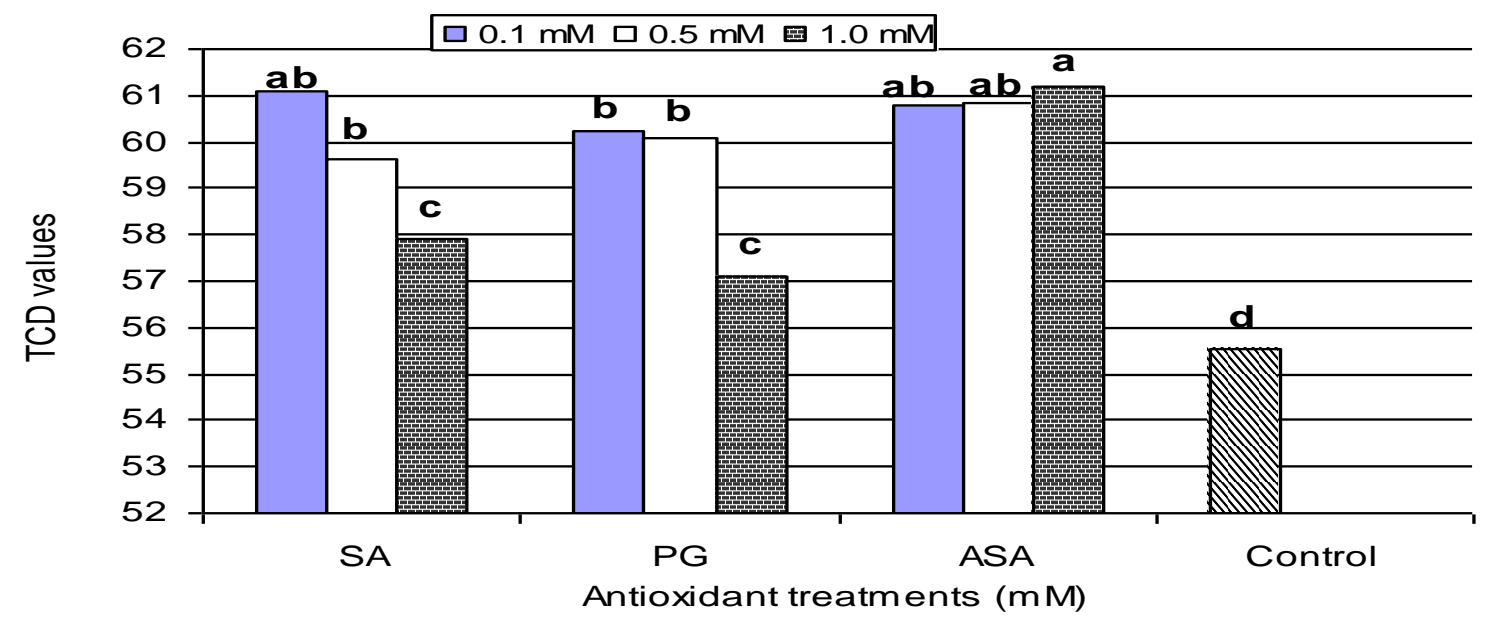

Values with similar alphabetical letter do not significantly differ from each other, using Duncan's Multiple Range test, at 0.05 levels.

Fig. (9): Color and TCD values of dried meal potato tuber slices cv. "Diamant" as affected by some antioxidant treatments (SA, PG and ASA) at different concentrations. 
that the color values of the dried meal potato tubers slice treatments were affected by the antioxidant treatments and play a role in improving the lightness (L) and yellowness (b). Using SA at $0.1 \mathrm{mM}, \mathrm{PG}$ at 0.5 and $1.0 \mathrm{mM}$ and ASA at the three levels significantly improved the lightens with insignificance between them. Highly significant differences were recorded by ASA at $1.0 \mathrm{mM}$ (83.56) as compared with the control (78.68). On the contrary, SA and PG at $1.0 \mathrm{mM}$ recorded the lowest values. All treatments recorded the lowest values in the color redness as compared with the control. Also, these treatments recorded the highest values in the yellowness (bvalues) as compared with the control. Both SA at $0.1 \mathrm{mM}$ and ASA at the three levels recorded the highest TCD values with insignificant between them. These results indicate that ASA is a highly effective reducing agent in improving the TCD colour value than SA or PG in the prevention of enzymatic browning either by reducing o-quinones to colourless diphenols, or by reacting irreversibly with o-quinones to form stable colourless products (Maurice et al., 2000). Also, data presented by Yamamato et al., (2004) showed that enzymatic browning requires oxygen, an enzyme, copper and substrates. The rate of enzymatic browning in fruits and vegetables is governed by the active of polyphenol oxidase (PPO) content of the tissues. ASA may act as an oxygen scavenger for the removal of molecular oxygen in PPO reactions.

It could be concluded that: a- Propylgallate at $1.0 \mathrm{mM}$ improved the pigment contents, yield (ton /fed.), plant height $(\mathrm{cm})$, dry matter, specific gravity, and starch. b- Low levels of these antioxidant treatments (at $0.1 \mathrm{mM}$ ) improved the production of potato seed tubers (culturable). cImprovement in the reduction of the potato feathering \% with using SA at $1.0 \mathrm{mM}$, SA may play a role in the promotion of senescence (aging, effects of old age) with the highest level. dAcetylsalicylic acid (Aspirin) was effective in improving the colour value of potato tubers.

3.8. Acknowledgement: The authors thanks Dr. S. H. Gad El-Hak Prof. of Vegetables , Hort. Dept. Faculty of Agriculture. El-Minia University for helping and reviewing the present work.

\section{REFERENCES}

A. O. A. C. (Association of Official Analytical Chemists). (1990). Official methods of analysis, $15^{\text {th }}$ Ed., Washington, D. C., USA.

Arnon D. I. (1949). Copper enzymes in isolated chloroplasts polyphenol oxidase in Beta vulgaris. Plant Physiology., 24: 115.

Bi Y. M., Kenton P., Murr L., Darby R. and Draper J. (1995). $\mathrm{H}_{2} \mathrm{O}_{2}$ does not function downstream of salicylic acid in the iduction of PR protein expression. Plant J. 8: 235-245.

Bordersen P., Malinovsky F. G., Henaty K., Newman M. A. and Mundy J. (2005). The role of salicylic acid in the induction of cell death in Arabidopsis acdll. Plant Physiology. 138: 1037-1045.

Chen H. J. and Kuc' J. J. (1999). $\mathrm{Ca}^{2+}$-dependent excretion of salicylic acid in tobacco cell suspension culture. Botanical Bulletin of Academia Sinica. 40: 267-273

Chen H. J., Hou W. C., Kuc' J. and Lin Y. H. (2001). $\mathrm{Ca}^{2+}$-dependent and $\mathrm{Ca}^{2+}$ independent excretion modes of salicylic acid in tobacco cell suspension culture. J. of Experimental Botany 52: 1219-1226.

Duncan D. B. (1955). Multiple range and multiple F tests. Biometrics 11:142.

Einhellig F. A. (1986). In The Science of Allelopathy (Putnam, A. R., and Tang, C. S., eds) p. 317, Wiley, New York.

Elad Y. (1992). The use of antioxidants (free radical scavengers) to control grey mould (Botrytis cinerea) and white mould (Sclerotinia sclerotiorum) in various crops.Plant Pathology. 41: 417-426.

Galal A. A., Hussien N. A., Abd EL-Latif M. R. and Armanious H. A. H. (2001). Control of cotton root rot wilt by ascorbic acid, propylgallate, thiourea and benlate. First Conf. of Alternative of Pesticides for Pest Management . Assiut Univ., Egypt (October, 28-29.). 61-69.

Gilmore A. M. and Yamamoto H. Y. (1991). Resolution of lutein and zeaxanthin using a non-endcapped. Lightly carbon-loaded $\mathrm{C}_{18}$ high-performance liquid chromatographic column. J Chromatogr. 543: 137-145.

Godoy-Hernandez G. and Loyola-Vargas V. M. (1997). Effect of acetylsalicylic acid on secondary metabolism of Catharanthus roseus tumor suspension cultures. Plant Cell Reports. (16): 287-290.

Gould W. A. and Plimpton S. L. (1985). Qulaity evaluation of potato cultivars for processing. Ohio Ag Res Dev Cent Res Bull 1172.

Hodges D. H and Forney C. F. (2000). The effects of ethylene depressed oxygen and elevated carbon dioxide on antioxidant profiles of senescing spinach leaves. J. Exp. Bot. 51:645655. 
Iyengar R. and McEvil A. J. (1992). Antibrowning agents alternatives to the use of sulfites in foods. Trends Food Sci. Technol. 3, 60-64

Johnson G. N., Scholes J. D., Horton P. and Young A. (1993). Plant Cell Envir. 16: 681686.

Kahkonen M .M., Hopia A. L., Vuorela H. J., Rauha J. P., Pihlaja K., Kujala T.S. and Heinonen M. (1999). Antioxidant activity of plant extracts containing phenolic compounds. J. Agric. Food Chem. 47:3954-3962.

Kalt W. C., Forney F., Martin A. and Prior R. L. (1999). Antioxidant capacity, vitamin C, phenolics and anthocyanins after fresh storage of small fruits. J. Agric. Food Chem. 47: 4638-4644.

Kapulnik Y., Yalpani N. and Raskin I. (1992). Salicylic acid induces cyanide-resistance respiration in tobacco cell suspension cultures. Plant Physiology 100: 1921-1926.

Karadeniz F., Burdurlu H. S., Koca N. and Soyer Y. (2005). Antioxidant activity of selected fruits and vegetables grown in Turkey. Turk.J. Agric. 29: 297-303.

Kaur M. and Singh N. (2005). Studies on functional, thermal and pasting properties of flours from different chickpea (Cicer arietinumL.) cultivars. Food Chemistry. 91: 403-411.

Kauss H. and Jeblick W. (1994) Pre-treatment of parsley suspension cultures with salicylic acid enhances spontaneous and elicited production of $\mathrm{H}_{2} \mathrm{O}_{2}$. Plant Physiology. 108: 1171-1178

Kawano T., Sahashi N., Takahashi K., Uozumi N. and Muto S. (1998). Salicylic acid induced extracellular superoxide generation followed by an increase in cytosolic calcium ion in tobacco cell suspension culture: The earliest events in salicylic acid signal transduction. Plant and Cell Physiology 39, 721-730.

Kawano T., Furuich T. and the late Muto S. (2004). Controlled salicylic acid levels and corresponding signaling mechanisms in plants. Plant Biotechnology 21: 319-335.

Klessige D. F. and Malamy J. (1994). The salicylic acid signal in plants. Plant Mol. Biol. 26: 1439.

Koda Y., Takahashi K. and Kikuta Y. (1992). Potato tuber-inducing activities of salicylic acid and related compounds. Journal of Plant Growth Regulation. 11: 215-219.

Limpo S. and Piergiovanni L. (2006). Shelf life of minimally processed potatoes. Part 1 . Effects of high oxygen partial pressures in combinations with ascorbic and citric acid on enzymatic browning. Postharvest Biology and Technology. 39: 254-264.

López-Delgado H. and Scott I. M. (1996). Acetylsalicylic acid: its effects on a highly expressed phosphatase from Solanum cardiophyllum. Biotechnol. Apl.13:186-189.

López-Delgado H. and Scott I. M. (1997). Induction of in Vitro tuberization of potato microplants by acetylsalicylic acid. J. Plant. Physiol. 151:74-78.

López-Delgado H., Dat J. F., Foyer C. H., and Scott I. M. (1998). Induction of thermo tolerance in potato microplants by acetylsalicylic acid and $\mathrm{H}_{2} \mathrm{O}_{2}$. Exp Bot 49: 713-720.

López-Delgado H., Mora-Herrera M. E., ZavaletaMancera H. A., Cadena-Hinojosa M. and Scott I. M. (2004). Salicylic acid enhances heat tolerance and potato virus $\mathrm{X}$ (PVX) elimination during thermotherapy of potato microplants. Amer. J. Potato Res. 81:161-166.

López-Delgado H., Zavaleta-Mancera H. A., Mora-Herrera M. E., Zquez-Rivera M. V., Flores-Gutirrez F. X. and Scott I. M. (2005). Hydrogen peroxide increases potato tuber and stem starch content, stem diameter and stem lignin content. Potato Association of America Jul/Aug. 2005. Article. 1/7/2005

Matus-Cadiz M. A., Hucl P., Perron C. E. and Tyler R. T. (2003). Genotype x Environment interaction for grain color in hard white spring wheat. Crop Sci. 43:219-226.

Maurice R. M., Kim J. and Wei C. I. (2000). Enzymatic browning in fruits, vegetables and seafoods. Food Science and Human Nutrition Department. University of Florida, 2000.

Munne-Bosch S and Penuelas J. (2003). Photoand antioxidative protection, and a role for salicylic acid during drought and recovery in field-grown Phillyrea angustifolia plants. Planta. 217: 758-766.

Muriel J., Brien O. and Rich E. A. (1976). Potato diseases. Agriculture Handbook. No. 474. Washington, D.C. 20402

Pan Q., Zhan J., Liu H., Zhang J., Chen J., Wen P. and Huang W. (2006). Salicylic acid synthesized by benzoic acid 2- hydroxylase participates in the development of thermotolerance in pea plants. Plant Science. 171:226-233.

Paterson T. J., Baxter G., Lawrence J. and Duthie G. ( 2006). Is there a role for dietary salicylates in health? Proc. Nutr. Soc. 65 (1): 93-6.

Pierpoint W. W. S. (1994). Salicylic acid and its derivatives in plants: medicines, metabolites 
and messenger molecules. Adv. Bot. Res. 20: 165-235.

Rajagopal S., Joly D., Gauthier A., Beauregard M. and Carpentier R. (2005). Protective effect of active oxygen scavengers on protein degradation and photochemical function in photosystem I submbrane fractions during light stress. FEBS.J. 272: 892-902.

Rao M. V., Paliyath G., Ormrod D. P., Murr D. P. and Watkins C. B. (1997). Influence of salicylic acid on $\mathrm{H}_{2} \mathrm{O}_{2}$ production, oxidative stress, and $\mathrm{H}_{2} \mathrm{O}_{2}$-metabolizing enzymes. Plant Physiol. 115: 137-149.

Raskin I., Turner I. M. and Melander W. R. (1989). Regulation of heat production in the inflorescence of an Arum lily by endogenous salicylic acid. Proceedings of National Academy of Sciences, USA 86, 2214-2218.

Raskin I., Skubatz H., Tang W. and Meeuse B. J. D. (1990). Salicylic acid levels in thermogenic and non-thermogenic plants. Annals of Botany 66, 369-373.

Raskin I.(1992). Role of salicylic acid in plants. Annual Review of Plant Physiology Plant Molecular Biology 43, 439-463.

Roberts D. R., Kristie D. N., Thompson J. E., Dumbroff E. B. and Gepstein S. (1991). In vitro evidence for the involvement of activated oxygen in light induced aggregation of thylakoid proteins. Physiological Plantarum. 82: 389.

Senaratna, T., Touchell D., Bunn E. and Dixon K. (2000). Acetyl salicylic acid (Aspirin) and salicylic acid induce multiple stress tolerance in bean and tomato plants. Plant Growth Regulation 30: 157-161.

Siefermann-Harms D. (1987). The light-harvesting and protective functions of carotenoids in photosynthetic membranes. Physiol Plant. 69: 561-568.

Sinha N. K., Cash J. N. and Chase R. W. (1992). Differences in sugars, chip color, specific gravity and yield of selected potato cultivars grown in Michigan. Amer Potato J. 69: 385-389.

Sonoike K. (1996). Degradation of psaB gene product, the reaction center subunit of photosystem I, is caused during photoinhibition of photosystem I: possible involvement of active oxygen species. Plant Sci 115, 157-164.

Stejskal D., Proskova J., Petrzelova A., Bartek J., Oral I., Lacnak B., Horalik D. and Sekaninova S. (2001). Application of cationic propylgallate as inducer of thrombocyte aggregation for evaluation of effectiveness of antiaggregation therapy. Biomed. Papers. 145 (2), 69-74.

Storey R. M. J. and Davies H. V. (1992). Tuber quality. In: PM Harris (ed), The Potato Crop: The Scientific Basis for Improvement, Ed 2. Chapman and Hall, London, pp 507-569.

Wada L. and Ou B. (2002). Antioxidant activity and phenolic content of Oregon cranberries. J. Agric. Food Chem. 50: 3495-3500.

Yamamato T., Yoshimura M., Yamaguchi F., Kouchi T., Tsuji R., Saito M., Obata A. and Kikuchi M. (2004). Anti-allergic activity of Naringenin Chalcone from a tomato skin extract. Bioscience, Biotechnology and Biochemistry. 68: 1706-1711.

Yildrim Z. and Tokusoglu O. (2005). Some analytical quality characteristics of potato (Solanum tuberosum L.) minitubers (cv.NIF) developed via in vitro cultivation. Electronic J. of Environmental Agricultural and Food Chemistry. Ege University, Faculty of Agriculture, Department of Field Crops, 35100, Bornova, Izmir.

Zhou X. M., Mackenize A. F., Madramootoo C. A. and Smith D. L. (1999). Effects of Steminjected plant growth regulators, with or without sucrose, on grain production, biomass and photosynthetic activity of field-grown corn plants. J. Agronomy and Crop Science. 183: page 103.

Zolla L and Rinalducci S. (2002) Involvement of active oxygen species in degradation of lightharvesting proteins under light stresses. Biochemistry 41:14391-14402.

Zvomuya, F. and Rosen, C. J. (2001). Evaluation of polyolefin-coated urea for potato production on a sandy soil. Hort. Sci. 36 (6): 1057-1060. 


\section{دورالمعاملات بمضادات الأكسدة فى تحسين جودة وإنتاجية البطاطس \\ ناصر سيد يوسف - عيد محمد محمد عبدالله \\ قسم بحوث الخضر ـ معهد بحوث البساتين ـ مركز البحوث الزراعية ــ الجيزة ـ مصر}

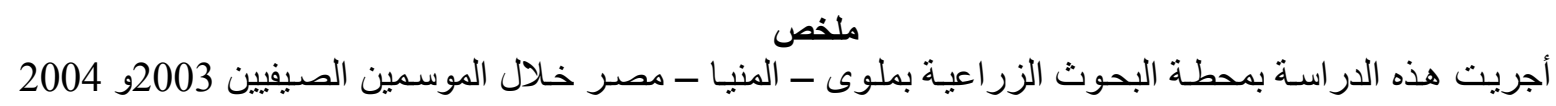

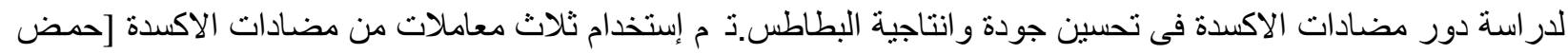

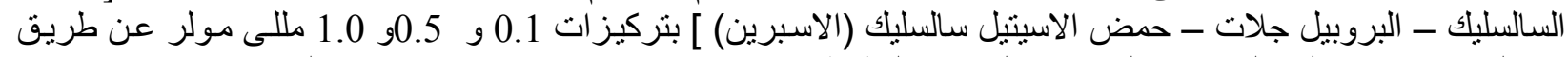

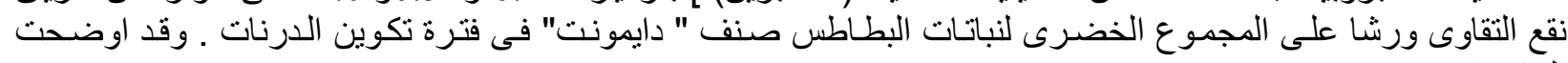

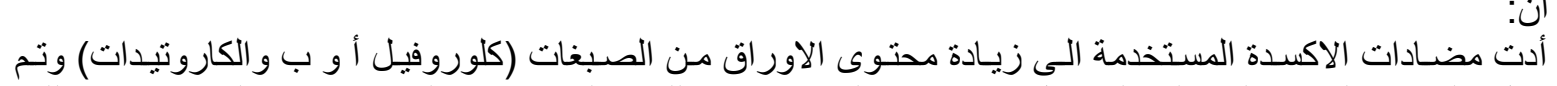

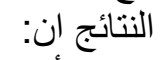

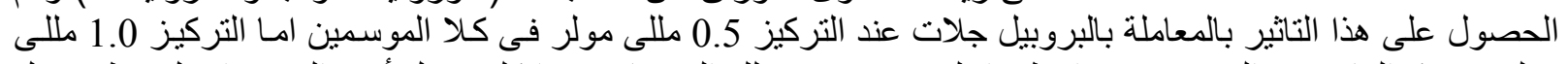

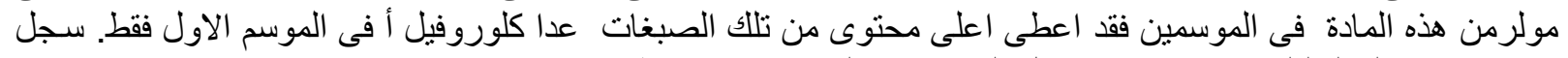

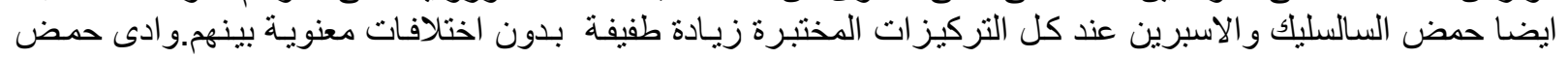

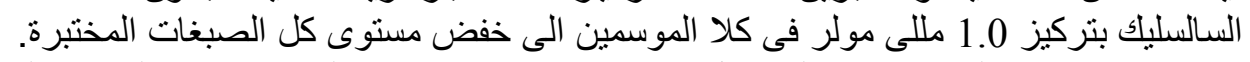

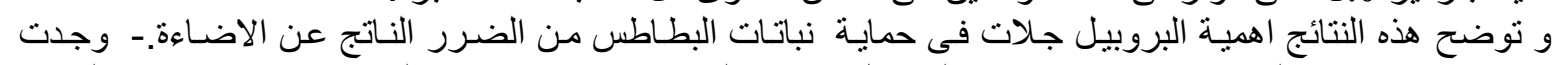

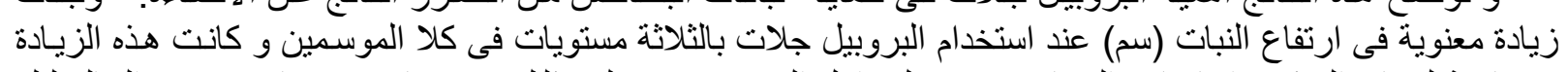

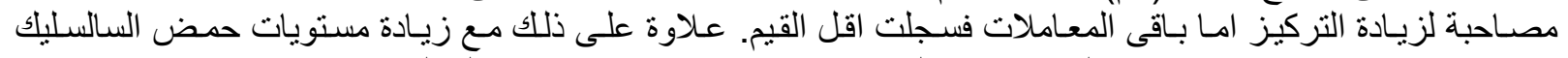

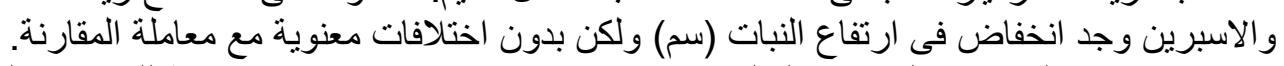

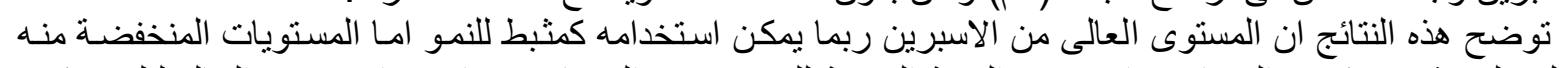

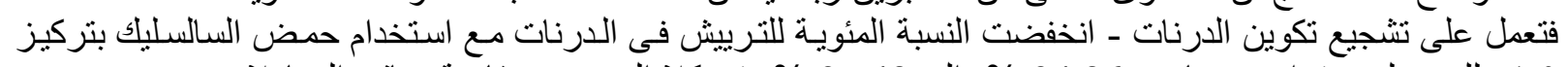

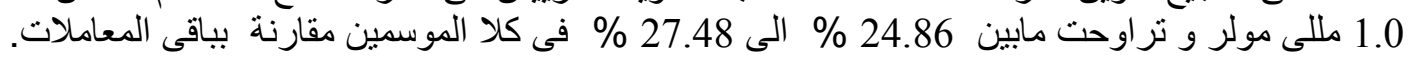

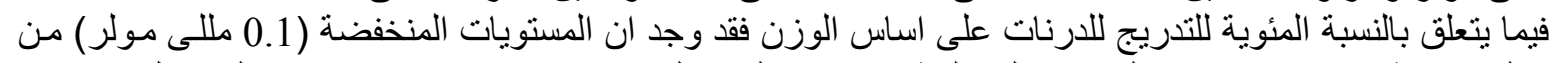

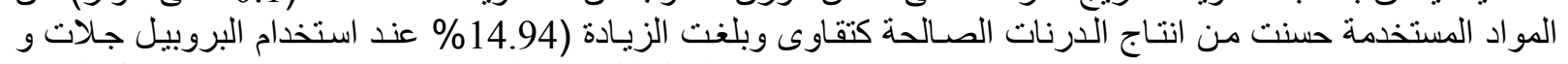

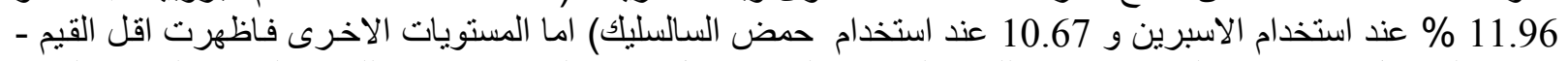

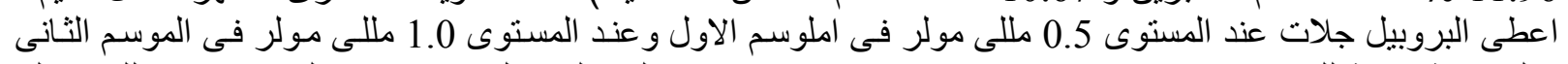

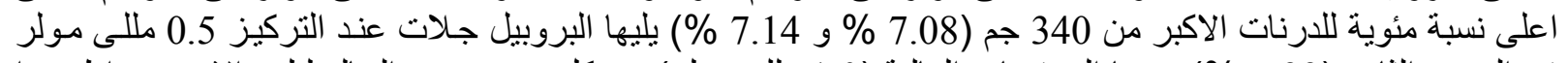

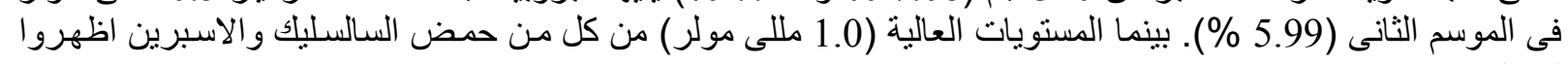

وجدت زيادة فى النسبة المئوية للمادة الجافة و الوزن النوعى و المحصول الكلى (طن/فدان) و الذى سجل زيادة مقدار ها

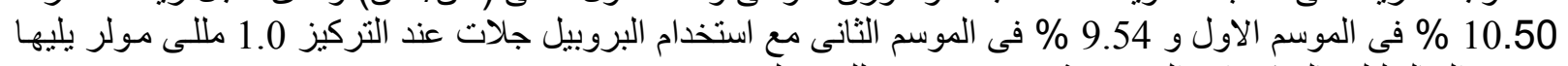

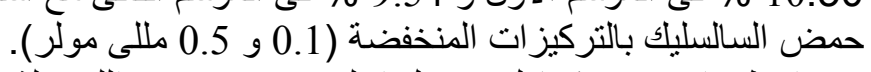

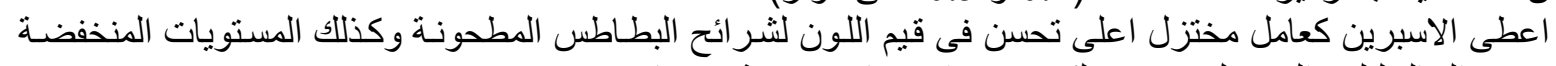

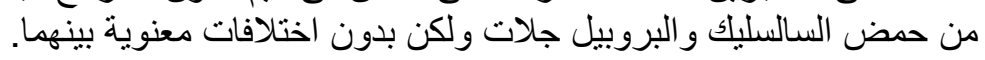
ويستخلص من النتائج الآتى:

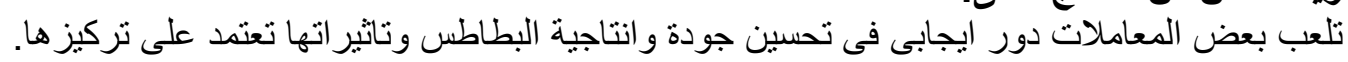

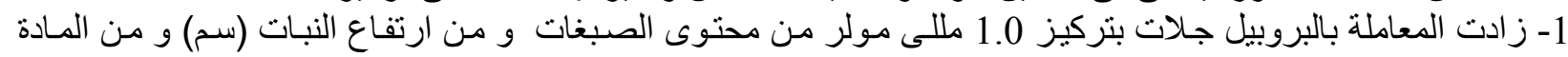

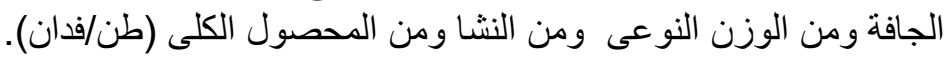

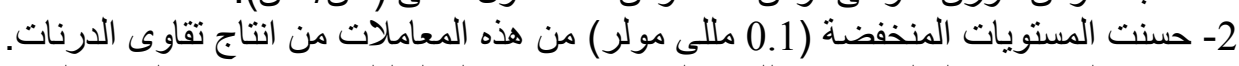

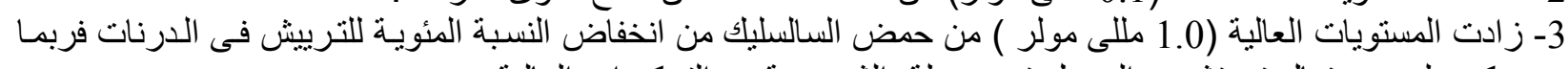

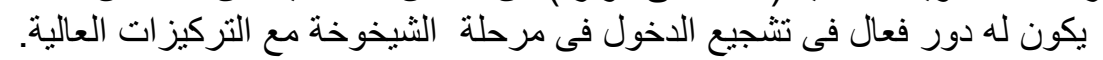

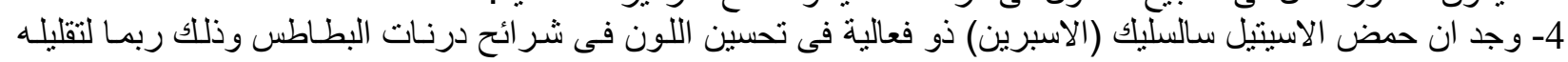

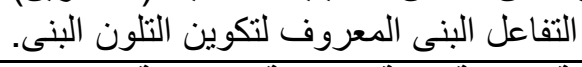

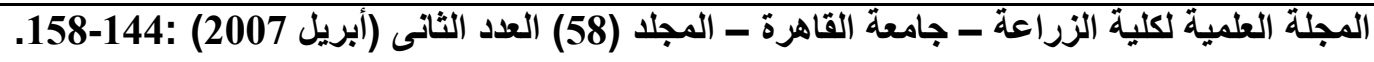

